\title{
Paraconiothyrium fuckelii, Diaporthe eres and Neocosmospora parceramosa causing cane blight of red raspberry in Northern Italy
}

\author{
Vladimiro Guarnaccia $^{1,2}$ (D) Ilaria Martino ${ }^{1} \cdot$ Luca Brondino $^{3} \cdot$ Maria Lodovica Gullino $^{1}$
}

Received: 3 September 2021 / Accepted: 1 February 2022 / Published online: 16 February 2022

(c) The Author(s) 2022

\begin{abstract}
Red raspberry (Rubus idaeus L.) represents a relevant crop which production has largely increased worldwide during the last decade. Cane blight is one of the most common diseases of red raspberry and it can produce considerable losses. During 2019-2021, surveys were conducted in red raspberry orchards in Cuneo province, Northern Italy, to investigate the etiology and pathogen diversity in association with cane blight. Eleven isolates were collected from symptomatic plants of the cultivars 'Diamond Jubilee' and 'Grandeur', and were identified through multi-locus phylogenies and morphological features. Three fungal species were identified: Paraconiothyrium fuckelii, Diaporthe eres and Neocosmospora parceramosa. Four different genomic regions were included in the molecular analyses: ITS, tefl, tub2 and rpb2. The species pathogenicity was confirmed and $P$. fuckelii was revealed as the most aggressive. This study provides an insight into raspberry cane blight in Italy and the genomic loci sequencing lay the basis to develop specific diagnostic protocols to monitor the presence of pathogens and to prevent disease spread, adopting effective integrated control strategies.
\end{abstract}

Keywords Rubus idaeus $\cdot$ Multi-locus typing $\cdot$ Etiology $\cdot$ Pathogenicity $\cdot$ Berry fruit

\section{Introduction}

Red raspberry (Rubus idaeus L., Rosaceae) is a deciduous shrub with a biennial cane habit. Raspberry cultivars can be primocane and floricane based on their fruiting habit (Martin et al. 2017). Primocane raspberries produce fruit during the fall of the first year and during the summer of the second year after plantation. Whilst, floricane fruiting raspberries produce berries only on the second year of growth. Primocane cultivars offer the convenience to extend the cropping season, with reduction of costs and higher fruit quality. Thus, different breeding programmes were conducted worldwide to promote the use of these cultivars and to increase yield, fruit

Vladimiro Guarnaccia

vladimiro.guarnaccia@unito.it

1 Centre for Innovation in the Agro-Environmental Sector, AGROINNOVA, University of Torino, Largo Braccini 2, 10095 Grugliasco, TO, Italy

2 Department of Agricultural, Forest and Food Sciences (DISAFA), University of Torino, Largo Braccini 2, 10095 Grugliasco, TO, Italy

3 Ortofruit Italia Soc. Agr. Coop. O.P, Via Colombaro dei Rossi 16/bis, 12037 Saluzzo, CN, Italy quality and biotic and abiotic stress tolerance (Graham and Brennan 2018).

Red raspberry is considered a crop of global significance for its production and economic value and, due to the provided health benefits, its cultivation has increased worldwide (Graham and Brennan 2018; Retamales and Hancock 2012; Zhang et al. 2018). Europe is a leading region for raspberry production with more than 103,000 ha cultivated mainly in the northern and eastern regions (FAOSTAT 2020). In Italy, during the last decade, an increasing interest was observed in berry fruit cultivation and raspberry production achieved 2,280 tonnes with 360 ha cultivated in 2020 (FAOSTAT 2020). The rising importance of this crop led to more intensive cultivation systems (Graham and Brennan 2018). All berry fruit crops represent an expanding sector within Italian agriculture; they are included among the major fresh fruit exported during the last decade (FAOSTAT 2020). Orchards are usually established under plastic nets and fibre cover or in plastic tunnels to increase the temperature and to extend the growing season of the crop (Graham and Brennan 2018; Retamales and Hancock 2012). However, the intensive production system, the introduction of plant material from foreign countries as well as new cultivars, can promote 
the introduction of emerging or new pathogens (Dolan et al. 2018). Cane blight represents one of the most relevant diseases caused by fungal pathogens on raspberry plants (Martin et al. 2017). The disease affects canes that were wounded during their vegetative year causing xylem infections, bud failure, lateral shoot wilt and, in severe cases, cane death. Lesions are usually represented by dark red to purple areas around wounds with irregular dark purple borders (Graham and Brennan 2018). The fungal species Paraconiothyrium fuckelii is reported as the causal agent of raspberry cane blight (Martin et al. 2017). Synonyms of this species are Leptosphaeria coniothyrium, Coniothyrium fuckelii, Microsphaeropsis fuckelii and Kalmusia coniothyrium (Damm et al. 2008; De Gruyter et al. 2013; MikulicPetkovsek et al. 2014; Verkley et al. 2004). Verkley et al. (2014) renamed it after a reassessment within the Montagnulaceae family. This pathogen is also known to cause stem canker of Rosa sp. (Horst and Cloyd 2007; Jamali 2020) and it was reported in association with other woody hosts species in the genera Malus, Prunus, Ribes and Vaccinium (Bérubé and Nicolas 2015; Chen et al. 2017; Farr and Rossman 2021). Paraconiothyrium fuckelii usually overwinters on dead floricanes as pseudothecia that produce ascospores or as pycnidia that produce conidia. Thus, old floricanes represent the primary source of inoculum in Rubus orchards (Martin et al. 2017). Little information is known about the infectivity of ascospores, whilst conidia could be dispersed by splashing rains from early spring to late autumn and could enter through cane wounds causing infection and considerable losses in raspberry production (Dolan et al. 2018).

Girichev et al. (2018) reported raspberry cane disease as caused by a complex of different phytopathogenic fungi. Moreover, several fungal species can survive as saprophytes on canes with a role in disease development (Girichev et al. 2018). Thus, it is necessary to clearly understand the etiology of raspberry cane blight to identify the fungal species associated with symptomatic or asymptomatic plant materials and their role in the disease development. Previous studies reported the influence of the raspberry genotype on the resistance to cane diseases caused by Botrytis cinerea, Didymella applanata and Leptosphaeria coniothyrium (White et al. 1990). Therefore, etiological studies on pathogens related to different raspberry cultivars could set the basis for new breeding programs.

Several berry fruit orchards were monitored over a three years period (2019-2021) in Piedmont, Northern Italy.
Etiological and pathogenic studies were conducted to (i) assess the fungal species diversity associated with raspberry cane blight using molecular and phylogenetic tools, (ii) to characterize the species phenotypes, and (iii) to test the pathogenicity of the species found on different cultivars, fulfilling Koch's postulates.

\section{Materials and methods}

\section{Field sampling and fungal isolation}

During the period May 2019 to April 2021, surveys were conducted in three raspberry plantations in Falicetto, Lagnasco and Manta (Cuneo, Piedmont, Italy) (Table 1). Samples from whole symptomatic plants of the primocane cultivars 'Grandeur' and 'Diamond Jubilee' were collected from the part showing stripe lesions on canes, and transferred in the laboratory. Disease incidence (DI) was assessed on 100 observed plants in each of the three orchards, and the average percentage of symptomatic plants was determined. Twenty symptomatic plants were collected from each orchard. The wood samples $(5-10 \mathrm{~mm})$ were surface sterilised in $1 \%$ sodium hypochlorite for $1 \mathrm{~min}$, rinsed in sterile distilled water (SDW) for $1 \mathrm{~min}$ and dried on sterile absorbent paper. Small fragments $(2-3 \mathrm{~mm})$ were cut from the margin between healthy and necrotic tissues and plated on potato dextrose agar (PDA, Oxoid) amended with $25 \mathrm{ppm}$ of streptomycin sulphate (PDA-S, Sigma-Aldrich). The plates were incubated at $25 \pm 1^{\circ} \mathrm{C}$ under a $12 \mathrm{~h}$ photoperiod. Following 48 to $72 \mathrm{~h}$ of incubation, mycelium plugs from the margins of resulting colonies were placed on new PDA plates. After $5 \mathrm{~d}$, pure cultures were established from single hyphal tip transfers. A total of 11 isolates were obtained and 11 of these were selected based on colony aspect and used for molecular characterization (Table 2). Stock cultures of these isolates are kept at $-80{ }^{\circ} \mathrm{C}$ in the AGROINNOVA Centre of Competence (University of Torino) culture collection, Torino, Italy.

\section{DNA extraction, polymerase chain reaction (PCR) amplification, and sequencing}

Genomic DNA was extracted from $0.1 \mathrm{~g}$ of mycelium grown on PDA, using the E.Z.N.A. Fungal DNA Mini Kit (Omega Bio-Tek), following the manufacturer's instructions. Species
Table 1 Coordinates and location of the orchards monitored in this study $\mathrm{DI}=$ Disease Index assigned at the beginning of the surveys

\begin{tabular}{lllll}
\hline $\mathbf{N}^{\circ}$ orchard & Site (City, Region) & Coordinates & Rubus idaeus cultivar & DI \\
\hline 1 & Verzuolo (Cuneo, Piedmont) & $44^{\circ} 35^{\prime} 49.1^{\prime \prime N} 7^{\circ} 30^{\prime} 10.2^{\prime \prime} \mathrm{E}$ & 'Grandeur' & $80 \%$ \\
2 & Lagnasco (Cuneo, Piedmont) & $44^{\circ} 37^{\prime} 20.9^{\prime \prime} \mathrm{N} 7^{\circ} 33^{\prime} 05.6^{\prime \prime} \mathrm{E}$ & 'Diamond jubilee' & $70 \%$ \\
3 & Verzuolo (Cuneo, Piedmont) & $44^{\circ} 35^{\prime} 51.8^{\prime \prime} \mathrm{N} 7^{\circ} 30^{\prime} 02.4^{\prime \prime} \mathrm{E}$ & 'Grandeur' & $80 \%$ \\
\hline
\end{tabular}


Table 2 Collection details and GenBank accession numbers of isolates included in this study

\begin{tabular}{|c|c|c|c|c|c|c|c|}
\hline \multirow[t]{2}{*}{ Species } & \multirow[t]{2}{*}{ Culture No. ${ }^{a}$} & \multirow[t]{2}{*}{ Locality } & \multirow[t]{2}{*}{ Host } & \multicolumn{4}{|c|}{ GenBank No. ${ }^{b}$} \\
\hline & & & & ITS & tef1 & $t u b 2$ & $r p b 2$ \\
\hline Diaporthe acaciigena & CBS 129,521 & Australia & Acacia retinoges & KC343005 & KC343731 & KC343973 & - \\
\hline D. ampelina & CBS $114016^{\mathrm{T}}$ & France & Vitis vinifera & AF230751 & GQ250351 & $\mathrm{JX} 275452$ & - \\
\hline D. amygdali & CBS $126679^{\mathrm{T}}$ & Portugal & Prunus dulcis & KC343022 & KC343748 & KC343990 & - \\
\hline D. arecae & CBS 535.75 & Suriname & Citrus sp. & KC343032 & KC 343758 & KC344000 & - \\
\hline D. australfricana & CBS 111886 & Australia & Vits vinifera & KC343038 & KC343764 & KC344006 & - \\
\hline D. baccae & CBS $136972^{\mathrm{T}}$ & Italy & Vaccinium corymbosum & KJ160565 & KJ160597 & MF418509 & - \\
\hline D. carpini & CBS 114437 & Sweden & Carpinus betulus & KC343044 & KC343770 & KC344012 & - \\
\hline D. citri & CBS 135422 & USA & Citrus sp. & KC843311 & KC843071 & KC843187 & - \\
\hline \multirow[t]{6}{*}{ D. eres } & CBS 101742 & Netherlands & Fraxinus sp. & KC343073 & KC343799 & KC344041 & - \\
\hline & CBS 116953 & New Zeland & Pyrus pyrifolia & KC343147 & KC 343873 & KC 344115 & - \\
\hline & CBS 138594 & Germany & Ulmus laevis & KJ210529 & KJ210550 & KJ420799 & - \\
\hline & CBS 143344 & Czech Republic & Vitis vinifera & MG281020 & MG281541 & MG281193 & - \\
\hline & CVG473* & Italy & $\begin{array}{l}\text { Rubus idaeus cv. 'Dia- } \\
\text { mond Jubilee' }\end{array}$ & MZ712970 & MZ717163 & MZ717170 & - \\
\hline & CVG474 & Italy & $\begin{array}{l}\text { Rubus idaeus cv. 'Dia- } \\
\text { mond Jubilee' }\end{array}$ & MZ712971 & MZ717164 & MZ717171 & - \\
\hline D. notophagi & BRIP54801 $^{\mathrm{T}}$ & Australia & $\begin{array}{l}\text { Notophagus cunning- } \\
\text { hamii }\end{array}$ & JX862530 & JX862536 & KF170922 & - \\
\hline D. perjuncta & CBS $109745^{\mathrm{T}}$ & Austria & Ulmus glabra & KC343172 & КC343898 & KC344140 & - \\
\hline D. rudis & CBS 113201 & Portugal & Vits vinifera & KC343234 & KC343960 & KC344202 & - \\
\hline D. rudis & CBS 266.85 & Netherlands & Rosa rugosa & KC343237 & КС343963 & KC344205 & - \\
\hline D. sterilis & CBS $136969^{\mathrm{T}}$ & Italy & Vaccinum corymbosum & KJ160579 & KJ160611 & KJ160528 & - \\
\hline D. toxica & CBS $594.93^{\mathrm{T}}$ & Australia & Lupinus angustifolis & KC343220 & KC343946 & KC344188 & - \\
\hline \multirow[t]{2}{*}{ D. vaccinii } & CBS 118571 & USA & Vaccinium corymbosum & KC343223 & KC343949 & KC344191 & - \\
\hline & CBS $160.32^{\mathrm{T}}$ & USA & Vaccinium macrocarpon & AF317578 & GQ250326 & KC344196 & - \\
\hline Diaporthella corylina & CBS $121124^{\mathrm{T}}$ & China & Corylus sp. & KC343004 & KC343730 & KC343972 & - \\
\hline Geejayesia cicatricum & CBS 125552 & Slovenia & Dead twig & HQ728145 & HM626644 & - & HQ728153 \\
\hline $\begin{array}{l}\text { Helminthosporium } \\
\text { solani }\end{array}$ & CBS 640.85 & The Netherlands & Solanum tuberosum & MH861907 & - & - & KY984403 \\
\hline $\begin{array}{l}\text { Neocosmospora } \\
\text { acutispora }\end{array}$ & CBS $145461^{\mathrm{T}}$ & Guatemala & Coffea arabica & LR583700 & LR583593 & - & LR583814 \\
\hline N. bostrycoides & CBS 392.66 & Unknown & Bertholletia excelsa & LR583705 & LR583598 & - & LR583819 \\
\hline N. brevicona & CBS $204.31^{\mathrm{ET}}$ & Indonesia & Gladiolus sp. & LR583707 & LR583600 & - & LR583821 \\
\hline N. brevis & CBS $144387^{\mathrm{T}}$ & Belgium & Polluted soilwater & LR583708 & LR583601 & - & LR583822 \\
\hline N. catenata & CBS 143228 & USA & Stegostoma fasciatum & KC808255 & KC808213 & - & KC808354 \\
\hline N. cyanescens & CBS $518.82^{\mathrm{T}}$ & Netherlands & Human foot & AB190389 & LR583605 & - & LR583826 \\
\hline N. diminuta & CBS $144390^{\mathrm{T}}$ & Unknown & Coelocaryon preusii & LR583713 & LR583607 & - & LR583828 \\
\hline N. falciformis & $\begin{array}{l}\text { CBS } 141593^{\mathrm{T}} \\
\text { (ex-type of } \\
\text { F. para- } \\
\text { naense) }\end{array}$ & Brazil & Glycine max & MG787463 & KF597797 & - & KF680011 \\
\hline N. gamtoosensis & CBS $146502^{\mathrm{T}}$ & South Africa & Citrus sinensis & MW173063 & MW248762 & - & MW218116 \\
\hline \multirow[t]{2}{*}{ N. hypothenemi } & CBS $145464^{\mathrm{T}}$ & Benin & Hypothenemus hampei & LR583715 & JF740850 & - & JF741176 \\
\hline & CBS 145466 & Uganda & Hypothenemus hampei & LR597067 & JF740851 & - & JF741177 \\
\hline N. keratoplastica & CBS $490.63^{\mathrm{T}}$ & Japan & Human & LR583721 & LT906670 & - & LT960562 \\
\hline N. lerouxii & CBS $146514^{\mathrm{T}}$ & South Africa & Citrus sinensis & MW173069 & MW248768 & - & MW218123 \\
\hline N. liriodendri & CBS $117481^{\mathrm{T}}$ & USA & Liriodendron tulipifera & AF178404 & AF178340 & - & EU329506 \\
\hline N. longissima & CBS $126407^{\mathrm{T}}$ & New Zealand & Tree bark & LR583731 & LR583621 & - & LR583846 \\
\hline \multirow[t]{2}{*}{ N. macrospora } & CBS $142424^{\mathrm{T}}$ & Italy & Citrus sinensis & LT746266 & LT746218 & - & LT746331 \\
\hline & CPC 28193 & Italy & Citrus sinensis & LT746268 & LT746220 & - & LT746333 \\
\hline
\end{tabular}


Table 2 (continued)

\begin{tabular}{|c|c|c|c|c|c|c|c|}
\hline \multirow[t]{2}{*}{ Species } & \multirow[t]{2}{*}{ Culture No. ${ }^{a}$} & \multirow[t]{2}{*}{ Locality } & \multirow[t]{2}{*}{ Host } & \multicolumn{4}{|c|}{ GenBank No. ${ }^{b}$} \\
\hline & & & & ITS & tef1 & tub2 & $r p b 2$ \\
\hline N. martii & CBS $115659^{\mathrm{ET}}$ & Germany & Solanum tuberosum & JX435206 & JX435156 & - & JX435256 \\
\hline N. metavorans & CBS $135789^{\mathrm{T}}$ & Greece & Human pleural effusion & LR583738 & LR583627 & - & LR583849 \\
\hline \multirow[t]{8}{*}{ N. parceramosa } & CBS $115695^{\mathrm{T}}$ & South Africa & Soil & JX435199 & JX435149 & - & JX435249 \\
\hline & NRRL 31158 & USA & Human wound & DQ094389 & DQ246916 & - & EU329559 \\
\hline & NRRL 32301 & USA & Human eye & EU329677 & DQ246929 & - & EU329567 \\
\hline & CVG461 & Italy & $\begin{array}{l}\text { Rubus idaeus cv. 'Dia- } \\
\text { mond Jubilee' }\end{array}$ & MZ712976 & MZ717165 & - & MZ717180 \\
\hline & CVG462* & Italy & $\begin{array}{l}\text { Rubus idaeus cv. 'Dia- } \\
\text { mond Jubilee' }\end{array}$ & MZ712977 & MZ717166 & - & MZ717181 \\
\hline & CVG682 & Italy & $\begin{array}{l}\text { Rubus idaeus cv. 'Gran- } \\
\text { deur' }\end{array}$ & MZ712978 & MZ717167 & - & MZ717182 \\
\hline & CVG684 & Italy & $\begin{array}{l}\text { Rubus idaeus cv. 'Gran- } \\
\text { deur' }\end{array}$ & MZ712979 & MZ717168 & - & MZ717183 \\
\hline & CVG685 & Italy & $\begin{array}{l}\text { Rubus idaeus cv. 'Gran- } \\
\text { deur' }\end{array}$ & MZ712980 & MZ717169 & - & MZ717184 \\
\hline \multirow[t]{2}{*}{ N. perseae } & CBS $144142^{\mathrm{T}}$ & Italy & Persea americana & LT991940 & LT991902 & - & LT991909 \\
\hline & CBS 144143 & Italy & Persea americana & LT991941 & LT991903 & - & LT991910 \\
\hline \multirow[t]{4}{*}{ N. petroliphila } & CBS 203.32 & South Africa & Pelargonium sp. & DQ094320 & DQ246835 & - & LR583857 \\
\hline & CBS 398.66 & Brazil & Saccharum officinarum & LR583749 & LR583633 & - & LR583859 \\
\hline & NRRL 22141 & New Zealand & Cucurbita sp. & DQ094307 & AF178329 & - & EU329491 \\
\hline & NRRL 22142 & USA & Cucurbita sp. & AF178411 & AF178347 & - & FJ240379 \\
\hline N. pisi & CBS 178.47 & The Netherlands & Pisum sativum & LR583751 & LR583634 & - & LR583860 \\
\hline \multirow[t]{2}{*}{ N. pseudoradicicola } & CBS $145472^{\mathrm{T}}$ & Papua New Guinea & Diseased cocoa pods & JF740899 & JF740757 & - & JF741084 \\
\hline & NRRL 25138 & Papua New Guinea & Diseased cocoa pods & JF740900 & JF740758 & - & JF741085 \\
\hline N. solani & $\begin{array}{l}\text { CBS } 101018 \mathrm{~T} \\
\text { (ex-type of } \\
\text { N. rubicola) }\end{array}$ & Italy & Rubus idaeus & LR583770 & LR583651 & - & LR583878 \\
\hline N. spathulata & CBS145474 ${ }^{\mathrm{T}}$ & USA & Human synovial fluid & EU329674 & DQ246882 & - & EU329542 \\
\hline N. vasinfecta & CBS 446.93 & Japan & Soil & LR583791 & LR583670 & - & LR583898 \\
\hline $\begin{array}{l}\text { Paraconiothyrium } \\
\text { africanum }\end{array}$ & CBS 121,166 & South Africa & Prunus persica & EU295650 & - & JX496368 & - \\
\hline P. archidendri & CBS 168.77 & Myanmar & $\begin{array}{l}\text { Archidendron bigemi- } \\
\quad \text { num }\end{array}$ & JX496049 & - & JX496388 & - \\
\hline \multirow[t]{2}{*}{ P. brasiliense } & CBS 100299 & Brazil & Culture from holotype & MH862698 & - & JX496350 & - \\
\hline & STE-U 6300 & South Africa & Prunus persica & EU295632 & - & - & - \\
\hline P. cyclothyrioides & CBS 972.95 & Papua New Guinea & Unknown & JX496119 & - & JX496458 & - \\
\hline P. estuarinum & CBS 109,850 & Brazil & Culture from holotype & MH862842 & - & JX496355 & LT854937 \\
\hline \multirow[t]{8}{*}{ P. fuckelii } & CBS 508.94 & - & Rosa sp. & JX496096 & - & JX496435 & - \\
\hline & CBS 584.69 & - & Gymonosperm & JX496098 & - & JX496437 & - \\
\hline & CBS 764.71B & The Netherlands & Unknown & JX496112 & - & JX496451 & - \\
\hline & CBS 797.95 & The Netherlands & Unknown & JX496113 & - & JX496452 & - \\
\hline & CVG482* & Italy & $\begin{array}{l}\text { Rubus idaeus cv. 'Dia- } \\
\text { mond Jubilee' }\end{array}$ & MZ712973 & - & MZ717173 & MZ717177 \\
\hline & CVG969 & Italy & $\begin{array}{l}\text { Rubus idaeus cv. 'Gran- } \\
\text { deur' }\end{array}$ & MZ712974 & - & MZ717174 & MZ717178 \\
\hline & CVG970 & Italy & $\begin{array}{l}\text { Rubus idaeus cv. 'Gran- } \\
\text { deur' }\end{array}$ & MZ712975 & - & MZ717175 & MZ717179 \\
\hline & CVG1017 & Italy & $\begin{array}{l}\text { Rubus idaeus cv. 'Gran- } \\
\text { deur' }\end{array}$ & MZ712972 & - & MZ717172 & MZ717176 \\
\hline P. fungicola & CBS 113269 & Albania & $\begin{array}{l}\text { Resupinate polypore } \\
\text { fungus }\end{array}$ & JX496020 & - & JX496359 & - \\
\hline
\end{tabular}


Table 2 (continued)

\begin{tabular}{|c|c|c|c|c|c|c|c|}
\hline \multirow[t]{2}{*}{ Species } & \multirow[t]{2}{*}{ Culture No. ${ }^{a}$} & \multirow[t]{2}{*}{ Locality } & \multirow[t]{2}{*}{ Host } & \multicolumn{4}{|c|}{ GenBank No. ${ }^{b}$} \\
\hline & & & & ITS & tef1 & tub2 & $r p b 2$ \\
\hline P. hawaiiense & CBS $120025^{\mathrm{T}}$ & USA & Sophora chrysophylla & DQ885897 & - & JX496366 & - \\
\hline P. sporulosum & CBS 358.75A & The Netherlands & Unknown & AJ293815 & - & - & - \\
\hline \multirow[t]{2}{*}{ P. variabile } & CBS 120014 & Italy & Actinidia chinensis & JX496026 & - & JX496365 & - \\
\hline & CBS 119486 & Italy & Actinidia chinensis & EF055359 & - & JX496362 & - \\
\hline $\begin{array}{l}\text { Paraphaeosphaeria } \\
\text { minitans }\end{array}$ & CBS 860.71 & Germany & Unknown & JX496117 & - & JX496456 & - \\
\hline
\end{tabular}

${ }^{a}$ BRIP: Plant Pathology Herbarium, Department of Primary Industries, Dutton Park, Queensland, Australia; CBS: Westerdijk Fungal Biodiversity Institute, Utrecht, the Netherlands; CVG: AGROINNOVA, Grugliasco, Torino, Italy; NRRL: Agricultural Research Service Culture Collection, National Center for Agricultural Utilization Research, US Department of Agriculture, Peoria, IL, USA; STEU: University of Stellenbosch, Stellenbosch, South Africa. Ex-type and ex-epitype cultures are indicated with ${ }^{\mathrm{T}}$

bITS: internal transcribed spacers 1 and 2 together with 5.8S nrDNA; tub2: beta-tubulin gene; tef1: translation elongation factor 1-alpha gene; $r p b 2$ : RNA polymerase second largest subunit. Sequences generated in this study indicated in red. * Isolates used for phenotypic characterization and pathogenicity test

identification was achieved through DNA amplification and sequencing of a combined dataset of genes: the nuclear ribosomal internal transcribed spacer (ITS) region, partial regions of the $\beta$-tubulin (tub2), translation elongation factor-1 $\alpha$ (tefl) and RNA polymerase second largest subunit (rpb2) genes. The primers used for each locus found are reported in Table 3. The PCR amplification mixtures and cycling conditions adopted for the analyses of ITS, tub2, tefl conducted on Paraconiothyrium isolates were followed as described in Aveskamp et al. (2009) and Zhang et al. (2009). The ITS, tub2, tef1 regions analysed for Diaporthe isolates were amplified according to PCR protocols reported by Guarnaccia and Crous (2018). For the isolates identified as Neocosmospora isolates, the protocols were adopted according to Guarnaccia et al. (2021) for the ITS, tefl and first part of $r p b 2$ loci. For the part of $r p b 2$ region amplified with the primers RPB2-7cf and RPB2-11ar, the PCR protocol by Yilmaz et al. (2020) was optimized as follows: $95{ }^{\circ} \mathrm{C} 1 \mathrm{~min} ; 40$ cycles of $95{ }^{\circ} \mathrm{C} 45 \mathrm{~s}, 52{ }^{\circ} \mathrm{C} 90 \mathrm{~s}, 72{ }^{\circ} \mathrm{C}$
$2 \mathrm{~min} ; 72{ }^{\circ} \mathrm{C} 10 \mathrm{~min}$ and adding BSA to the mixture $(1.5 \mu \mathrm{l}$ as final volume in a total volume of $25 \mu$ l per sample). An amount of $5 \mu \mathrm{l}$ of PCR product for each PCR reaction was examined by electrophoresis at $100 \mathrm{~V}$ on $1 \%$ agarose (VWR Life Science AMRESCO ${ }^{R}$ biochemicals) gels stained with GelRed $^{\mathrm{TM}}$. PCR products were purified and sequenced in both directions by Eurofins Genomics Service (Ebersberg). The DNA sequences generated were analysed and consensus sequences were computed using the program Geneious v. 11.1.5 (Auckland, New Zealand; Kearse et al. 2012).

\section{Phylogenetic analyses}

New sequences obtained in this study were BLASTed against the NCBI's GenBank nucleotide database to determine the closest relatives for a taxonomic framework of the studied isolates. Alignments of different gene regions, including sequences obtained from this study and sequences downloaded from GenBank, were initially
Table 3 Primers used in this study for molecular analyses

\begin{tabular}{llll}
\hline Locus & Primer name & Primer sequence 5'->3' & Reference \\
\hline ITS & ITS1 & TCCGTAGGTGAACCTGCGG & White et al. (1990) \\
& ITS4 & TCCTCCGCTTATTGATATGC & \\
$r p b 2$ & RPB2-5f2 & GGGGWGAYCAGAAGAAGGC & Liu et al. (1999) \\
& RPB2-7cr & CCCATRGCTTGYTTRCCCAT & \\
& RPB2-7cf & ATGGGYAARCAAGCYATGGG & Sung et al. (2007) \\
& RPB2-11ar & GCRTGGATCTTRTCRTCSACC & \\
$t$ tef1 2 & TUB2Rd & GTBCACCTYCARACCGGYCARTG & Aveskamp et al. (2009) \\
& TUB4Fd & CCRGAYTGRCCRAARACRAAGTTGTC & \\
& EF1-728f & CATCGAGAAGTTCGAGAAGG & Carbone and Kohn (1999) \\
& EF1-986r & TACTTGAAGGAACCCTTACC & \\
& EF1-983f & GCYCCYGGHCAYCGTGAYTTYAT & Rehner and Buckley (2005) \\
& EF1-2218r & ACHGTRCCRATACCACCRATCTT & \\
\hline
\end{tabular}


performed with the MAFFT v. 7 online server (http:// mafft.cbrc.jp/alignment/server/index.html) (Katoh and Standley 2013), and then manually adjusted in MEGA v. 7 (Kumar et al. 2016). After an initial analysis of the ITS locus (data not shown), a subset of representative isolates was selected to clearly distinguish the isolates at species level. Phylogeny was processed through different analyses conducted individually for each locus (data not shown) and as multilocus sequence analyses, as described above. The phylogenies were based on Bayesian Inference (BI) and Maximum Parsimony (MP) for the multi-locus analyses. For BI, the best evolutionary model for each partition was determined using MrModeltest v. 2.3 (Nylander 2004) and incorporated into the analyses. MrBayes v. 3.2.5 (Ronquist et al. 2012) was used to generate phylogenetic trees under optimal criteria per partition. The Markov Chain Monte Carlo (MCMC) analysis used four chains and started from a random tree topology. The heating parameter was set at 0.2 and trees were sampled every 1,000 generations. Analyses stopped when the average standard deviation of split frequencies was below 0.01. The MP analyses were performed using Phylogenetic Analysis Using Parsimony (PAUP) v. 4.0b10 (Swofford and Sullivan 2003). Phylogenetic relationships were estimated by heuristic searches with 100 random addition sequences. Tree bisectionreconnection was used, with the branch swapping option set on 'best trees', with all characters weighted equally and alignment gaps treated as fifth state. Tree length, consistency index, retention index and rescaled consistence index were calculated for parsimony, and the bootstrap analyses (Hillis and Bull 1993) were based on 1,000 replications. Sequences generated in this study were deposited in GenBank (Table 2).

\section{Phenotypic characterization}

Agar plugs ( $5 \mathrm{~mm}$ diam.) of representative strains were taken from the edges of actively growing cultures on PDA-S and transferred onto the centre of $9 \mathrm{~cm}$ diam. Petri dishes containing PDA or malt extract agar (MEA; Oxoid). Diaporthe eres representative strain was also transferred on $1 \%$ water agar supplemented with sterile pine needles (PNA; Smith et al. 1996). All the plates were then incubated at $20-21{ }^{\circ} \mathrm{C}$ under a $12 \mathrm{~h}$ photoperiod to induce sporulation. Colony characters were observed after $10 \mathrm{~d}$, and culture colours were determined (Rayner 1970). Cultures were examined periodically for the development of conidiomata. Conidia characteristics were examined by mounting fungal structures in SDW, and the lengths and widths of 30 conidia were measured for each isolate using a light microscope at $\times 40$ magnification. The average and standard deviations of conidia dimensions were calculated.

\section{Pathogenicity tests}

Pathogenicity tests with representative isolates of the isolated species (P. fuckelii, D. eres and N. parceramosa) were performed to fulfil Koch's postulates. Representative isolates of each species (Table 2) were selected and inoculated on healthy raspberry plants (cv 'Grandeur' and 'Diamond Jubilee'). Each of the three fungal pathogens was inoculated onto 8 raspberry plants of each cultivar, with a total of 24 plants inoculated with pathogens. A sterile scalpel was used to remove the outer bark of the cane at 3-4 $\mathrm{cm}$ from the crown. Mycelium plugs (4 mm diam.) were taken from 10-day-old cultures on PDA and placed with the mycelium in contact with the internal plant tissues. The inoculation points were wrapped with Parafilm ${ }^{\mathrm{R}}$. A further 8 plants of each cultivar were treated with sterile PDA plugs as inoculation controls. All the plants were placed in a growth chamber at $24{ }^{\circ} \mathrm{C}$ for 6 weeks. After this period, the lengths of lesions developed on the internal cane tissues were measured after peeling off the bark. Fifteen days after inoculation, the symptom severity (SS) associated with each inoculated species was evaluated as the length of vascular discolouration which were measured upward and downward from the inoculation points. Small portions $(0.3 \mathrm{~cm})$ of symptomatic tissue from the edge of cane lesions were placed onto PDA-S to re-isolate the fungal species, and these were identified based on their colony characteristics and ITS sequencing. This trial was conducted twice and each trial was considered a replicate. Because no normal distribution was observed in the lesion dimension data, the Kruskal-Wallis non-parametric test (at $P=0.05$ ) was performed to determine significant differences among the strains. The data analysis was conducted using SPSS software 26 (IBM Corporate).

\section{Results}

\section{Field sampling and fungal isolation}

Symptoms of cane blight were observed in all raspberry orchards surveyed. All the investigated crops were covered by anti-hail nets and presented relative humidity condition up to $78 \%$. Brown stripe lesions in correspondence of wounds were detected in the early stage of the disease. Later, the lesions progressively extended longitudinally trough the canes, showing cracking and causing the death of buds and lateral shoots. In several cases, lesions affected the vascular tissues with consequent cane decay and blight. Considerable vascular damage and cane death occurred in all the orchards and on both the cultivars investigated (Fig. 1). DI was assessed 


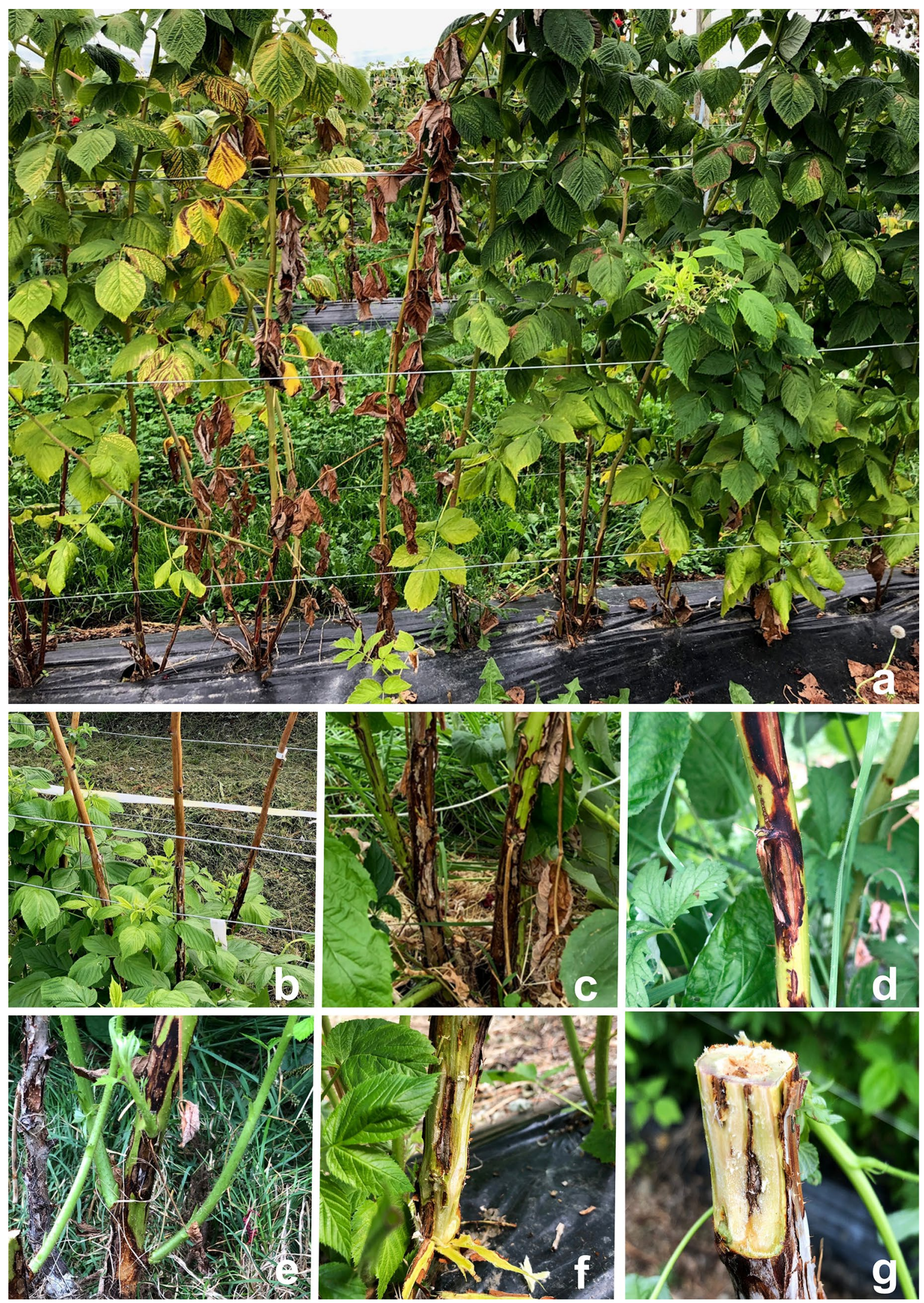

Fig. 1 Natural cane blight of Rubus idaeus 'Grandeur' in the field with wilt (a) and defoliation (b). External lesions (c, e), cracking (d) and vascular discolouration of the canes $(\mathbf{f}, \mathbf{g})$ 
as reported in Table 1. Based on colony morphology, phylogenetic analyses, and conidia characteristics (see below), D. eres was isolated from plant of the cultivar 'Diamond Jubilee', whilst $P$. fuckelii and $N$. parceramosa were isolated from both 'Diamond Jubilee' and 'Grandeur' plants.

\section{Phylogenetic analyses}

The combined-locus phylogeny of Paraconiothyrium consisted of 21 sequences, Diaporthe consisted of 23 sequences and Neocosmospora of 40, including outgroups. A total of 1,457 characters (ITS: $1-569$, tub2: 576-990 and rpb2: 997-1457) were included in the Paraconiothyrium phylogenetic analyses. A total of 1,400 characters (ITS: 1-554, tub2: 561-955 and tef1: 962-1400) were included in the Diaporthe phylogenetic analyses. The analyses for the Neocosmospora group consisted of 2,641 nucleotides (ITS: 1-467, tef1: 474-1131 and rpb2: 1138-2641). A maximum of 1,000 equally most parsimonious trees were saved, and characteristics of the combined gene partitions used for each phylogenetic analysis are reported in Table 4. Bootstrap support values from the parsimony analysis were plotted on the Bayesian phylogenies presented in Figs. 2, 3 and 4. Unique site patterns for each partition and all the parameters of the Bayesian analyses are reported in Table 4. For both of the Bayesian analyses, MrModeltest recommended the models reported in Table 5. In the Paraconiothyrium species analysis four isolates from symptomatic raspberry plants grouped with four reference strains of $P$. fuckelii (Fig. 2), whilst two isolates of Diaporthe clustered with four reference strains of D. eres (Fig. 3). The final tree generated for Neocosmospora species showed that five isolates clustered with the type specimen and two reference strains of $N$. parceramosa (Fig. 4).

\section{Phenotypic characterization}

Morphological observations, supported by phylogenetic inference, were described for three known species (Fig. 5).

\section{Paraconiothyrium fuckelii}

Ten-day-old colonies on PDA and MEA were woolly to floccose with pale grey aerial mycelium. Reverse bay, fading over sienna in the centre to pale luteous at the margin on MEA and bay to whitish at the margin on PDA. Colony diameter: $3.57 \pm 0.06 \times 3.54 \pm 0.06 \mu \mathrm{m}$ on PDA and $3.54 \pm 0.15 \times 3.23 \pm 0.15 \mu \mathrm{m}$ on MEA. Conidia variable in shape, subglobose to ellipsoid or obovoid, olivaceousbrown, 0 -septate, $4.2-2.7 \times 3-2.2 \mu \mathrm{m}$, mean $\pm \mathrm{SD}=3.28 \pm$ $0.4 \times 2.62 \pm 0.2$

\section{Diaporthe eres}

Ten-day-old colonies on PDA and MEA flat with pale grey to white moderate aerial mycelium, reverse pale grey on PDA and with black patches in the centre on MEA.

Table 4 Parsimony and Bayesian analyses characteristics in this study

\begin{tabular}{|c|c|c|c|c|}
\hline Phylogenetic analysis & Locus(i) & $\begin{array}{l}\text { Paraconiothyrium } \\
\text { ITS + tub2 + rpb2 }\end{array}$ & $\begin{array}{l}\text { Diaporthe } \\
\text { TS + tub2 + tef1 }\end{array}$ & $\begin{array}{l}\text { Neocosmospora } \\
\text { ITS + tef1 + rpb2 }\end{array}$ \\
\hline \multirow[t]{8}{*}{ Maximum Parsimony } & Total sites & 1445 & 1388 & 2529 \\
\hline & Constant sites & 899 & 607 & 1783 \\
\hline & Variable sites & 319 & 325 & 427 \\
\hline & Parsimony Informative sites & 227 & 456 & 319 \\
\hline & Tree length & 900 & 1910 & 1333 \\
\hline & Consistency index & 0,791 & 0,66 & 0,685 \\
\hline & Retention index & 0,784 & 0,708 & 0,708 \\
\hline & Rescaled consistence index & 0,621 & 0,467 & 0,485 \\
\hline \multirow[t]{7}{*}{ Bayesian inference } & Unique site patterns of ITS & 150 & 149 & 134 \\
\hline & Unique site patterns of tefl & - & 296 & 177 \\
\hline & Unique site patterns of $t u b 2$ & 152 & 186 & - \\
\hline & Unique site patterns of $r p b 2$ & 43 & - & 241 \\
\hline & Generation ran & 655,000 & 216,000 & 175,000 \\
\hline & Generated trees & 656 & 221 & 352 \\
\hline & Sampled trees & 492 & 77 & 259 \\
\hline
\end{tabular}




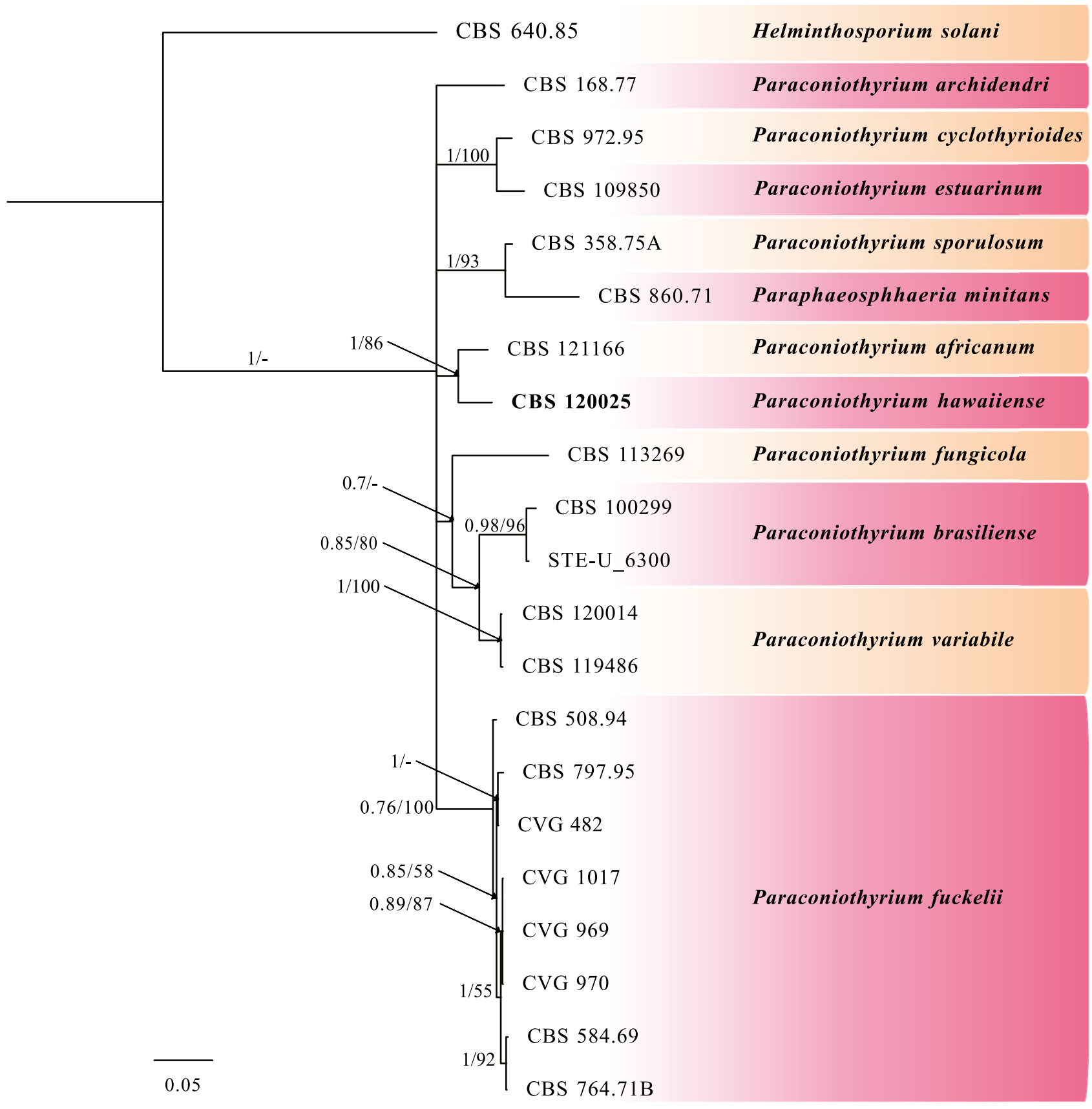

Fig. 2 Consensus phylogram of 656 trees resulting from a Bayesian analysis of the combined ITS, tub2 and rpb2 sequences of Paraconiothyrium strains. Bayesian posterior probability values and bootstrap

support values are indicated at the nodes. The tree was rooted to $\mathrm{Hel}$ minthosporium solani (CBS 640.85). Type specimens are indicated in bold

Colony diameter: $8.5 \pm 0.05 \times 6.24 \pm 1.99 \mu \mathrm{m}$ on PDA and $5.87 \pm 0.20 \times 5.24 \pm 1.19 \mu \mathrm{m}$ on MEA. Conidial mass globose to ellipsoidal, conidiomata pycnidial, sporulating, globose to conical, scattered, dark brown to black, superficial to embedded. Alpha conidia aseptate, hyaline,

smooth, oblong to ellipsoid, apex bluntly rounded, guttulate 7.2-3.2 $\times 3.0-1.9 \mu \mathrm{m}$, mean $\pm \mathrm{SD}=5.8 \pm 1.0 \times 2.46 \pm 0$ .3. Beta conidia hyaline, aseptate, smooth, spindle shaped, slightly curved $30.9-21.3 \times 1.4-0.8 \mu \mathrm{m}$, mean $\pm \mathrm{SD}=26.5$ $\pm 2.2 \times 1.1 \pm 0.2$. 


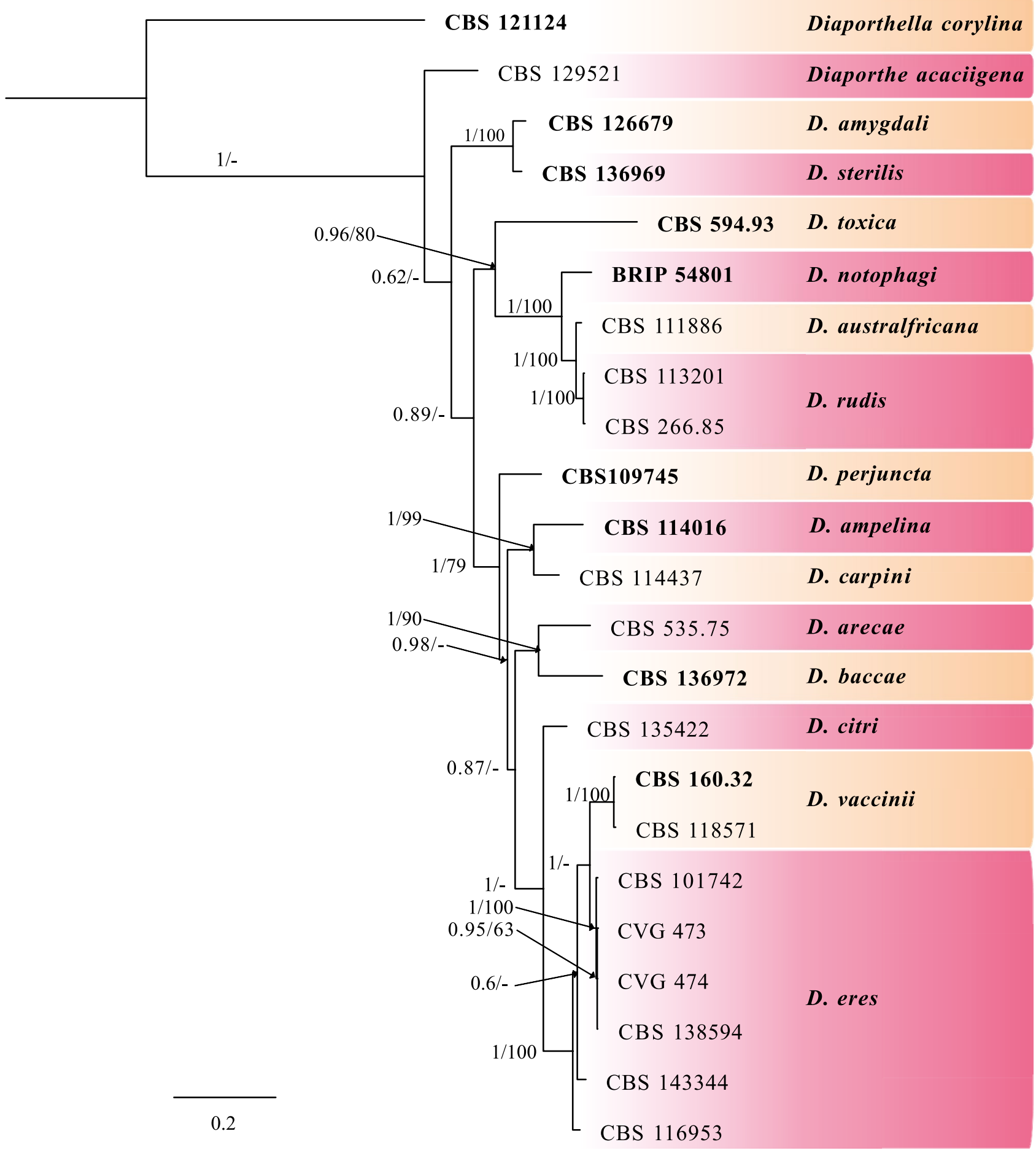

Fig. 3 Consensus phylogram of 221 trees resulting from a Bayesian analysis of the combined ITS, tub2 and tef1 sequences of Diaporthe strains. Bayesian posterior probability values and bootstrap support values are indicated at the nodes. The tree was rooted to Diaporthella corylina (CBS 121124). Type specimens are indicated in bold 


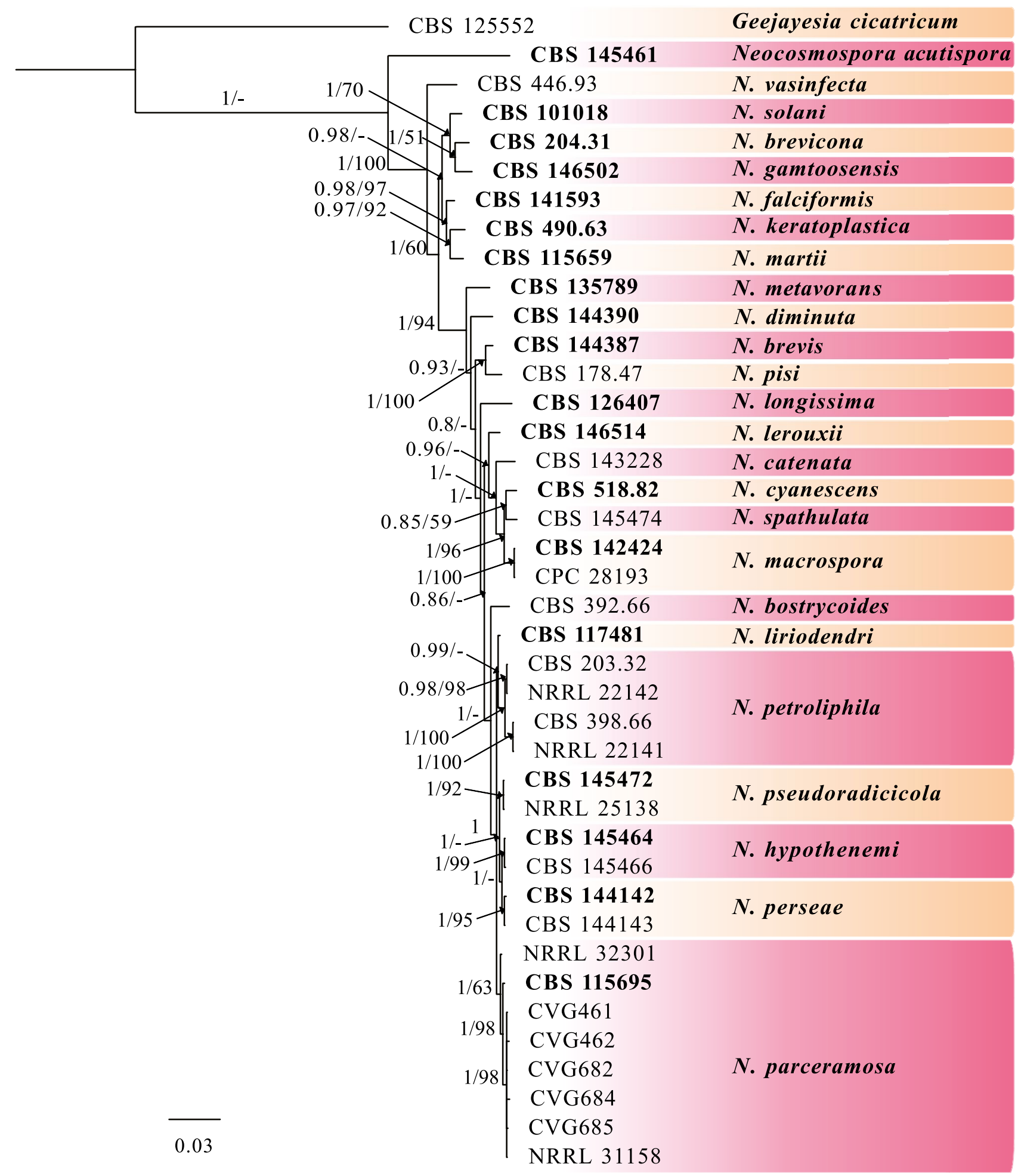

Fig. 4 Consensus phylogram of 352 trees resulting from a Bayesian analysis of the combined ITS, tef1 and rpb2 sequences of Neocosmospora strains. Bayesian posterior probability values and bootstrap

support values are indicated at the nodes. The tree was rooted to Geejayesia cicatricum (CBS 125552). Type specimens are indicated in bold 
Table 5 Evolutionary models as determined by MrModeltest (Nylander 2004)

\begin{tabular}{lll}
\hline Genus & Locus & Evolutionary model $^{\mathbf{a}}$ \\
\hline Paraconiothyrium & $\mathrm{ITS}$ & $\mathrm{GTR}+\mathrm{I}+\mathrm{G}$ \\
& $t u b 2$ & $\mathrm{~K} 80+\mathrm{G}$ \\
& $r p b 2$ & $\mathrm{SYM}$ \\
Diaporthe & $\mathrm{ITS}$ & $\mathrm{SYM}+\mathrm{I}+\mathrm{G}$ \\
& $t u b 2$ & $\mathrm{HKY}+\mathrm{G}$ \\
& $t e f 1$ & $\mathrm{GTR}+\mathrm{I}+\mathrm{G}$ \\
Neocosmospora & $\mathrm{ITS}$ & $\mathrm{SYM}+\mathrm{G}$ \\
& $t e f 1$ & $\mathrm{GTR}+\mathrm{G}$ \\
& $r p b 2$ & $\mathrm{SYM}+\mathrm{I}+\mathrm{G}$ \\
\hline
\end{tabular}

${ }^{a} \mathrm{G}$ : Gamma distributed rate variation among sites; GTR: Generalised time-reversible; HKY: Hasegawa-Kishino-Yano; I: Proportion of invariable sites; K80: Kimura's two parameter model; SYM: Symmetrical model

\section{Neocosmospora parceramosa}

Ten-day-old colonies on PDA flat, cottony to felty with white to pale straw aerial mycelium and entire margin, reverse straw to honey. Colony diameter: $5.43 \pm 0.06 \times 5.50 \pm 0.10 \mu \mathrm{m}$. Colonies produced microconidia ellipsoidal, subcylindrical to clavate, straight, hyaline, $7.8-4.2 \times 3.4-2.3 \mu \mathrm{m}$, mean $\pm \mathrm{SD}=5.75 \pm 0.98 \times 2.88 \pm 0$. 35 and macroconidia gently curved, 3-5-septate, hyaline, $45.3-31.9 \times 4.9-3.8 \mu \mathrm{m}$, mean $\pm \mathrm{SD}=40.39 \pm 3.44 \times 4.50$ \pm 0.36 .

\section{Pathogenicity tests}

After 60 days, all the tested isolates caused lesions and internal discolouration on the inoculated plants. In some cases, a severe dieback was observed and plant death occurred. Symptoms were similar to those found in the field-grown plants (Fig. 6). Re-isolation of pathogens was obtained with a frequency of grown colonies from small portions of affected tissues placed onto PDA-S between 90 and $95 \%$. The identification of the re-isolated species was confirmed using culture and molecular features, fulfilling Koch's postulates. Paraconiothyrium fuckelii has revealed to be the most aggressive species on both the inoculated cultivars causing vascular lesion of average length 5.1 and $4.0 \mathrm{~cm}$ on 'Grandeur' and 'Diamond Jubilee', respectively. Moreover, $P$. fuckelii caused the death of 2 of the inoculated 'Grandeur' and 1 of 'Diamond Jubilee' plants. Diaporthe eres and $N$. parceramosa caused less severe symptoms with mean vascular lesions length of 3.0 and $2.7 \mathrm{~cm}$ on 'Grandeur' and 'Diamond Jubilee', respectively, and $1.3 \mathrm{~cm}$ on both tested cultivars. The pairwise comparison obtained from the Kruskal-Wallis test, showed significant differences $(P<0.05)$ among the three isolates (Fig. 7).

\section{Discussion}

The increasing interest in berry fruit production promoted the development of new and improved commercial cultivars through several breeding programmes (Foster et al. 2019). Moreover, an intensification of the production systems through agronomic practices, use of irrigation systems and use of fertilizers, occurred to supply the consumers demand (Graham and Brennan 2018; Mezzetti 2014). However, the consequent consistent movement of plant materials and fruit favoured the spread of emerging diseases in different production areas (Dolan et al. 2018; Guarnaccia et al. 2020).

The present study was conducted in the most important fruit production area of Piedmont where a strong interest for raspberry cultivation is present. The study provides an investigation of the fungal pathogens associated with raspberry cane blight observed during the conducted surveys. Paraconiothyrium fuckelii, generally considered the causal agent of cane blight (Martin et al. 2017), was consistently isolated from symptomatic raspberry canes. Moreover, $D$. eres and $N$. parceramosa were found in association with cane blight disease and produced symptoms on artificially inoculated raspberry plants. The occurrence of different fungal species demonstrated the presence of a complex of fungi involved in the development of raspberry cane diseases as described by Girichev et al. (2018). Thus, considering the difficulty to distinguish different pathogens from symptoms or based on morphological traits, it becomes necessary the use of molecular tools to provide a correct identification (Girichev et al. 2018). The multi-locus analyses conducted in this work identified the three fungal pathogens. Paraconiothyrium fuckelii is known worldwide as the only causal agent of raspberry cane blight disease. It has been reported, with its previous taxonomic synonyms, on $R$. idaeus in Australia, Bulgaria, Canada, New Zealand, Poland, Russia and USA (Farr and Rossman 2021). In Italy, it has been found in association with withered grapes (Lorenzini et al. 2016).

Diaporthe spp. are important plant pathogens reported in association with stem bight and cankers of different fruit trees (Guarnaccia et al. 2020; Hilário et al. 2020; Yang et al. 2018). Their identification, mainly based on morphological traits and plant hosts, has resulted in a high number of described species. Thus, during the last years, multilocus phylogenies were adopted to reassess species within Diaporthe genus (Santos et al. 2017). The genomic loci sequencing provided in this study demonstrated the identification of 

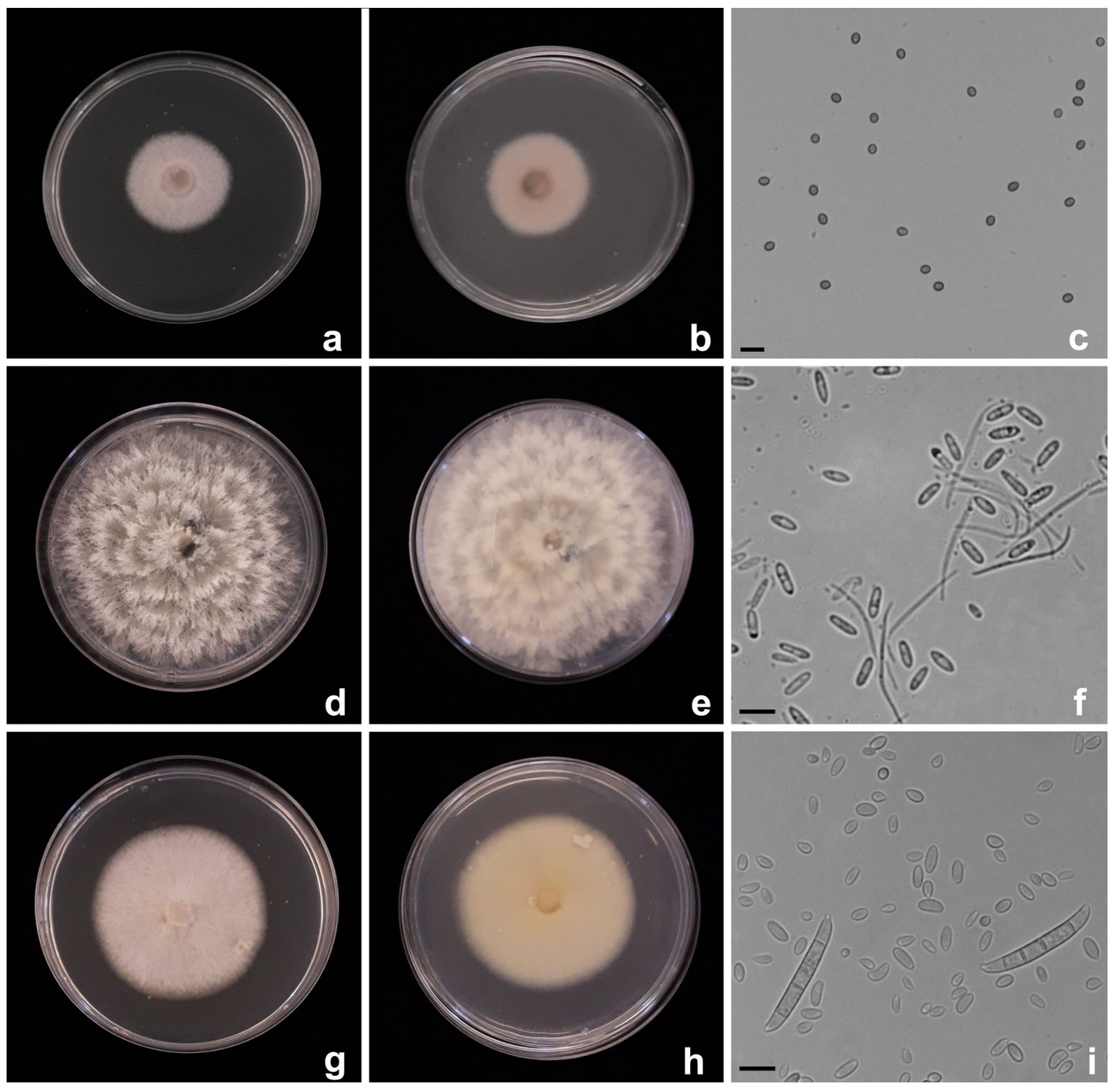

Fig. 5 Morphological characteristics of the different fungal species grown for $10 \mathrm{~d}$ on PDA. a, b and $\mathbf{c}$ Paraconiothyrium fuckelii; $\mathbf{d}$, e and $\mathbf{f}$ Diaporthe eres; $\mathbf{g}, \mathbf{h}$ and $\mathbf{i}$ Neocosmospora parceramosa. Scale bars $=10 \mu \mathrm{m}$

the isolated strains as $D$. eres. This species has been reported in association with raspberry cane disease in Germany and on other Rubus spp. in Austria, Croatia, France and Ireland (Farr and Rossman 2021). In Italy it has been isolated in association with stem blight on other fruit trees such as Castanea vesca, Ficus carica, Juglans regia, Prunus persica, Pyrus communis, Sambucus nigra and Vitis vinifera (Bertetti et al. 2018; Dissanayake et al. 2017; Prencipe et al. 2017).
Several Neocosmospora spp. have been reported in Italy as pathogenic on fruit crops such as Citrus spp., Ficus carica and Persea americana (Guarnaccia et al. 2018, 2019; Sandoval-Denis et al. 2018), however, N. parceramosa (synonym: Fusarium parceramosum) has been mainly isolated as presumed human pathogen and as present in plumbing systems, whilst the type specimen (CBS 115,695) was obtained from a soil sample collected in South Africa 
Fig. 6 Death of raspberry plant cv 'Diamond Jubilee' inoculated with Paraconiothyrium fuckelii compared with healthy control plant (a). Internal discoloration of plant cv 'Grandeur' with Diaporthe eres (b) and $P$. fuckelii (c)
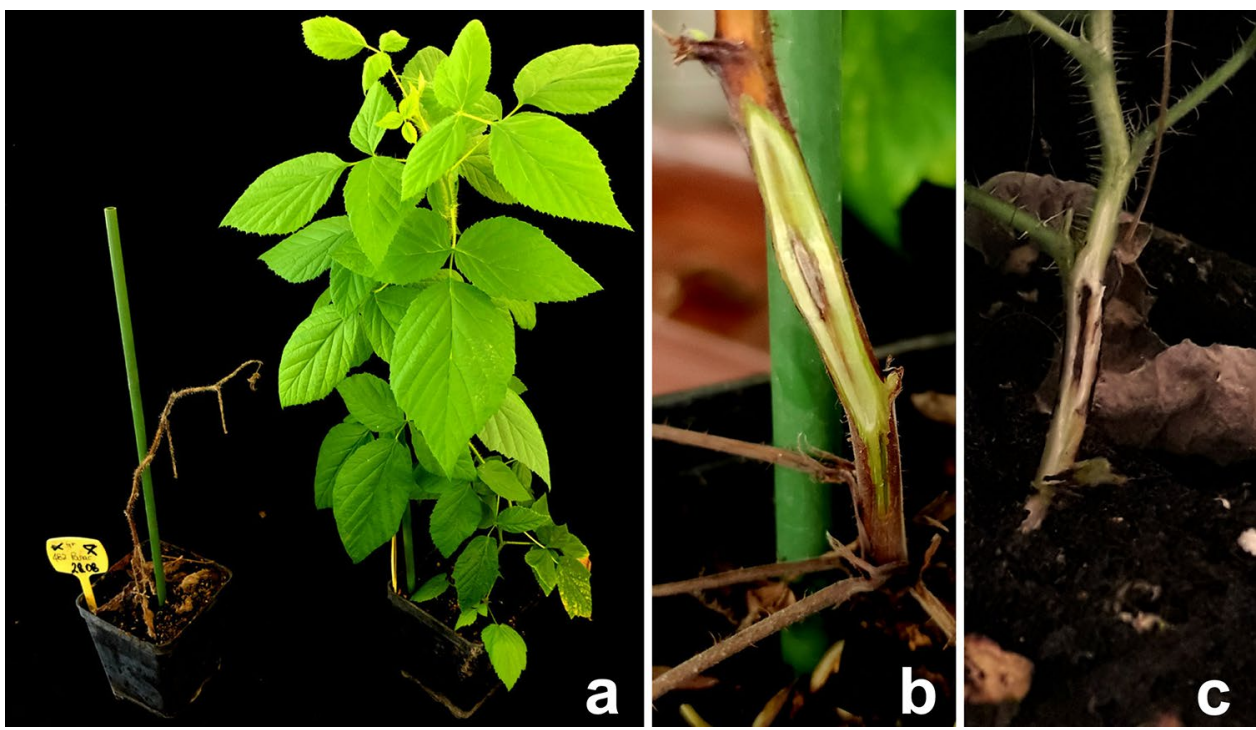

(Sandoval-Denis et al. 2019). The correct identification of this species was achieved by adding the second part of the $r p b 2$ region to the multi-locus sequence alignments analysed. Thus, demonstrating the importance of molecular diagnostic tools as reliable, objective, and necessary for correct species analysis. To our knowledge, this work represents the first report of $N$. parceramosa on $R$. idaeus in Italy and worldwide, and the first report of P. fuckelii and $D$. eres on raspberry in Italy.

The species collected during the surveys were confirmed as pathogenic. However, a different susceptibility among the tested cultivars was registered. Plants of the cv 'Grandeur' were consistently affected by the fungal pathogens and cane death occurred abundantly, whilst lower lesion length was observed on 'Diamond Jubilee' plants cv. Varietal resistance is a fundamental point to consider before orchard establishment, along with the use of certified plant materials. Favourable temperatures and high levels of relative humidity can also play a major role, thus, the interaction between found pathogens and environment temperature should be assayed. Moreover, good agronomic practices should be adopted to minimize the occurrence of wounds that can facilitate the pathogens entry within the vascular tissues. Providing correct distances among plants and regular cane thinning, reducing wound formation during berry harvesting, removing pruning debris and infected canes could be useful methods to reduce fungal pathogen spread, thus should be investigated.

Furthermore, it should be considered that weather conditions could promote pathogen and disease development.
Studies conducted on D. eres in Greece showed that this pathogen has an optimal growth at $25{ }^{\circ} \mathrm{C}$, however, considerable mycelial growth was assessed within the range $20-30{ }^{\circ} \mathrm{C}$ (Thomidis and Michailides 2009). Other analyses on water availability and relative humidity confirmed the influence of these abiotic factors on $D$. eres mycelial growth and conidia germination (Arciuolo et al. 2021). Wet and humid conditions have been reported as favourable also for Paraconiothyrium fuckelii development (Martin et al. 2017). Thus, periods with high temperature and high relative humidity could contribute to the spread of this pathogen. Moreover, cross infections within different plant hosts might occur, concurring to the diffusion of the disease among different orchards (Guarnaccia and Crous 2018). Further studies are needed to understand the epidemiology of raspberry cane blight with aim of monitoring disease occurrence and to develop prediction models for the adoption of effective management strategies.

In conclusion, the present work is the first insight into raspberry cane blight in Italy. The provided phylogenetic analyses and genomic loci sequencing set the basis for the development of species-specific diagnostic protocols to detect pathogen presence early in nursery and orchard environment. Further analyses are necessary to establish the role of abiotic factors and the relationships within the fungal species found in disease development and spread. The investigation of these aspects could permit the adoption of more sustainable management strategies and contribute to the constant reduction of chemical fungicides. 

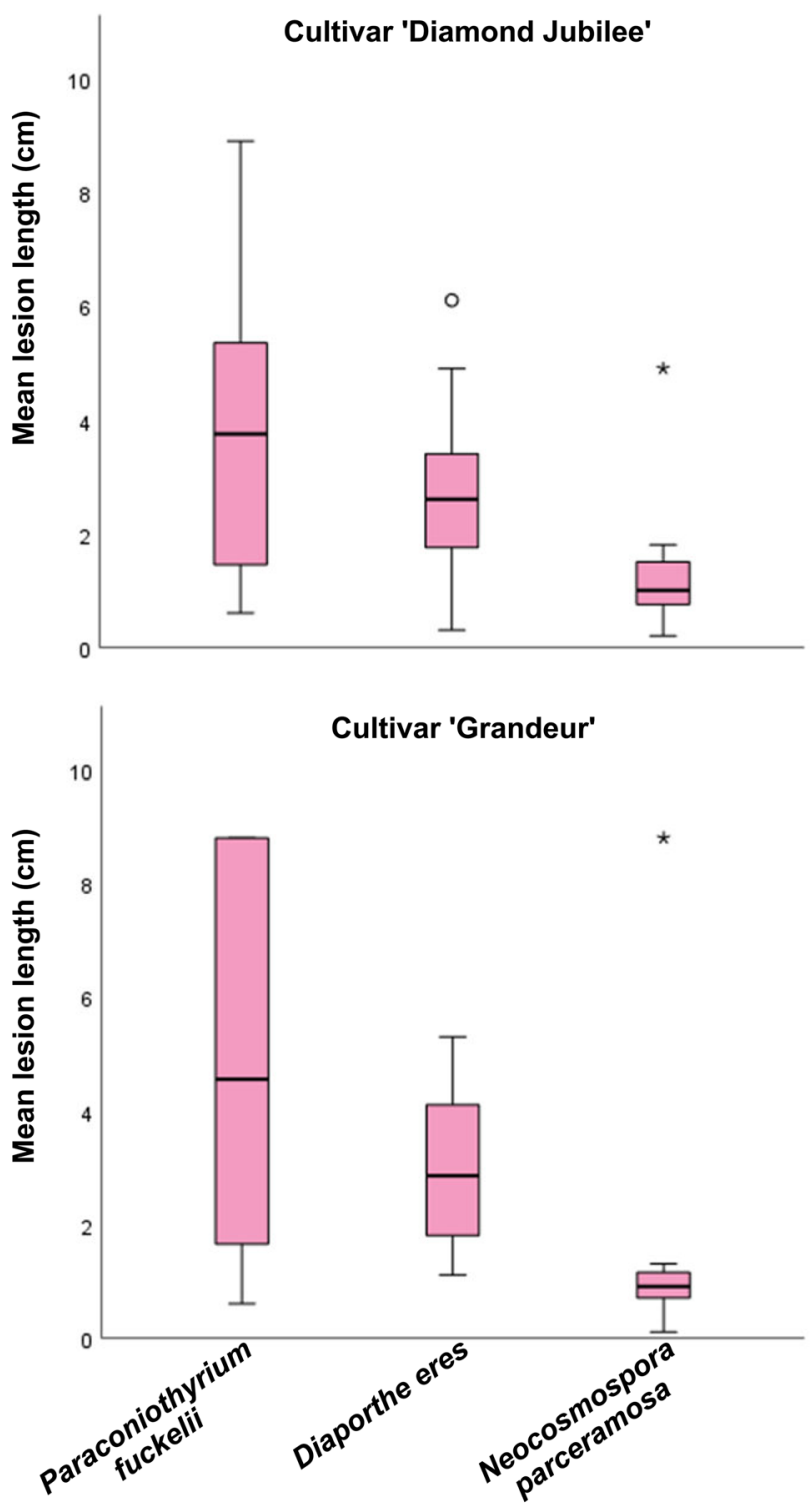

Fig. 7 Box plot showing the results of the pathogenicity tests. Boxes represent the interquartile range, while the horizontal line within each box indicates the average value. The Kruskal-Wallis test was carried out to compare the mean lesion lengths $(\mathrm{cm})$ from inoculation with three representative isolates. Significant difference was accepted for $P<0.05{ }^{\circ}$ Outliers. *: Extreme values

Acknowledgements This study was supported by Fondazione CRT in the project "Avversità del MIRtillo in Piemonte: dove e come combAtteRIE (MIRARE)".

Data availability The data that support the findings of this study are available from the corresponding author upon reasonable request. The data that support the findings of this study are available from.

Open Access This article is licensed under a Creative Commons Attribution 4.0 International License, which permits use, sharing, adaptation, distribution and reproduction in any medium or format, as long as you give appropriate credit to the original author(s) and the source, provide a link to the Creative Commons licence, and indicate if changes were made. The images or other third party material in this article are included in the article's Creative Commons licence, unless indicated otherwise in a credit line to the material. If material is not included in the article's Creative Commons licence and your intended use is not permitted by statutory regulation or exceeds the permitted use, you will need to obtain permission directly from the copyright holder. To view a copy of this licence, visit http://creativecommons.org/licenses/by/4.0/.

\section{References}

Arciuolo R, Camardo Leggieri M, Chiusa G, Castello G, Genova G, Spigolon N et al (2021) Ecology of Diaporthe eres, the causal agent of hazelnut defects. PLoS One 16:e0247563

Aveskamp MM, Verkley GJ, De Gruyter J, Murace MA, Perello A, Woudenberg JH et al (2009) DNA phylogeny reveals polyphyly of Phoma section Peyronellaea and multiple taxonomic novelties. Mycologia 101:363-382

Bertetti D, Guarnaccia V, Spadaro D, Gullino ML (2018) First report of fruit rot in European pear caused by Diaporthe eres in Italy. Plant Dis 102:2651

Bérubé JA, Nicolas GG (2015) Alien fungal species on asymptomatic live woody plant material imported into Canada. Can J Plant Path 37:67-81

Carbone I, Kohn LM (1999) A method for designing primer sets for speciation studies in filamentous ascomycetes. Mycologia 91:553-556

Chen SC, Zhao HJ, Wang MM, Jiang QY, Wang ZH, Liu AR et al (2017) First report of stem rot caused by Coniothyrium fuckelii on Morus alba in China. Plant Dis 101:387

Damm U, Verkley GJM, Crous PW, Fourie PH, Haegi A, Riccioni L (2008) Novel Paraconiothyrium species on stone fruit trees and other woody hosts. Pers Mol Phylogeny Evol Fungi 20:9

De Gruyter J, Woudenberg JHC, Aveskamp MM, Verkley GJM, Groenewald JZ, Crous PW (2013) Redisposition of Phoma-like anamorphs in Pleosporales. Stud Mycol 75:1-36

Dissanayake AJ, Phillips AJL, Hyde KD, Yan JY, Li XH (2017) The current status of species in Diaporthe. Mycosphere 8:1106-1156

Dolan A, MacFarlane S, Jennings SN (2018) Pathogens in raspberry and other Rubus spp. In Graham J., Brennan R. (eds) Raspberry. Springer, Cham. https://doi.org/10.1007/978-3-319-99031-6_4

FAOSTAT (2020) Food and Agriculture Organization of the United Nations. http://www.fao.org/faostat/en/\#home. Accessed 26 July 2021

Farr DF, Rossman AY (2021) Fungal databases U.S. National Fungus Collections ARS USDA

Foster TM, Bassil NV, Dossett M, Worthington ML, Graham J (2019) Genetic and genomic resources for Rubus breeding: A roadmap for the future. Hortic Res 6:1-9

Girichev V, von Reth M, Hanke MV, Höfer M, Schulte E, Flachowsky $\mathrm{H}$ (2018) Evaluation of Rubus genetic resources on their resistance to cane disease. Genet Resour Crop Evol 65:1979-1993

Graham J, Brennan R (eds) (2018) Raspberry: Breeding. Springer, Challenges and Advances

Guarnaccia V, Aiello D, Polizzi G, Crous PW, Sandoval-Denis M (2019) Soilborne diseases caused by Fusarium and Neocosmospora spp. on ornamental plants in Italy. Phytopathol Mediterr 58:127-137

Guarnaccia V, Crous PW (2018) Species of Diaporthe on Camellia and Citrus in the Azores Islands. Phytopathol Mediterr 57:307-319

Guarnaccia V, Martino I, Tabone G, Brondino L, Gullino ML (2020) Fungal pathogens associated with stem blight and dieback of blueberry in northern Italy. Phytopathol Mediterr 59:229-245 
Guarnaccia V, Sandoval-Denis M, Aiello D, Polizzi G, Crous PW (2018) Neocosmospora perseae sp. nov., causing trunk cankers on avocado in Italy. Fungal Syst Evol 1:131

Guarnaccia V, van Niekerk J, Crous P, Sandoval-Denis M (2021) Neocosmospora spp. associated with dry root rot of citrus in South Africa. Phytopathol Mediterr 60:79-100

Hilário S, Amaral IA, Gonçalves MF, Lopes A, Santos L, Alves A (2020) Diaporthe species associated with twig blight and dieback of Vaccinium corymbosum in Portugal, with description of four new species. Mycologia 112:293-308

Hillis DM, Bull JJ (1993) An empirical test of bootstrapping as a method for assessing confidence in phylogenetic analysis. Syst Biol 42:182-192

Horst RK, Cloyd RA (2007) Compendium of rose diseases and pests. Am Phytopathol Soc (APS Press)

Jamali S (2020) First report of Paraconiothyrium fuckelii (Didymosphaeriaceae, Pleosporales), causing stem canker in Rosa hybrida, from Iran. Czech Mycol 72:71-82

Katoh K, Standley DM (2013) MAFFT multiple sequence alignment software version 7: improvements in performance and usability. Mol Biol Evol 30:772-780

Kearse M, Moir R, Wilson A, Stones-Havas S, Cheung M, Sturrock S, Buxton S, Cooper A, Markowitz S, Duran C et al (2012) Geneious Basic: an integrated and extendable desktop software platform for the organization and analysis of sequence data. Bioinformatics 28:1647-1649

Kumar S, Stecher G, Tamura K (2016) MEGA7: molecular evolutionary genetics analysis version 7.0 for bigger datasets. Mol Biol Evol 33:1870-1874

Liu YJ, Whelen S, Hall BD (1999) Phylogenetic relationships among ascomycetes: evidence from an RNA polymerse II subunit. Mol Biol Evol 16(12):1799-1808

Lorenzini M, Cappello MS, Logrieco A, Zapparoli G (2016) Polymorphism and phylogenetic species delimitation in filamentous fungi from predominant mycobiota in withered grapes. Int $J$ Food Microbiol 238:56-62

Martin RR, Ellis MA, Williamson B, Williams RN (Eds.) (2017) Compendium of raspberry and blackberry diseases and pests (pp. 1-175) St Paul, MN: APS Press

Mezzetti B (2014) The sustainable improvement of European berry production, quality and nutritional value in a changing environment: strawberries, currants, blackberries, blueberries and raspberries-the EUBerry project. In XXIX International Horticultural Congress on Horticulture: Sustaining Lives, Livelihoods and Landscapes (IHC2014): II 1117:309-314

Mikulic-Petkovsek M, Schmitzer V, Stampar F, Veberic R, Koron D (2014) Changes in phenolic content induced by infection with Didymella applanata and Leptosphaeria coniothyrium, the causal agents of raspberry spur and cane blight. Plant Pathol 63:185-192

Nylander JAA (2004) MrModeltest v2. Program distributed by the author

Prencipe S, Nari L, Vittone G, Spadaro D (2017) First report of Diaporthe eres causing stem canker on peach (Prunus persica) in Italy. Plant Dis 101:1052-1052

Rayner RW (1970) A mycological colour chart. A mycological colour chart

Rehner SA, Buckley E (2005) A Beauveria phylogeny inferred from nuclear ITS and EF1- $\alpha$ sequences: evidence for cryptic diversification and links to Cordyceps teleomorphs. Mycologia 97:84-98

Retamales JB, Hancock JF (2012) Blueberries. CABI, Cambridge, MA, USA

Ronquist F, Teslenko M, Van Der Mark P, Ayres DL, Darling A, Höhna $S$ et al (2012) MrBayes 3.2: efficient Bayesian phylogenetic inference and model choice across a large model space. Syst Biol 61:539-542

Sandoval-Denis M, Guarnaccia V, Polizzi G, Crous PW (2018) Symptomatic Citrus trees reveal a new pathogenic lineage in Fusarium and two new Neocosmospora species. Pers Molec Phylogeny Evol Fungi 40:1

Sandoval-Denis M, Lombard L, Crous PW (2019) Back to the roots: a reappraisal of Neocosmospora. Pers Mol Phylogeny Evol Fungi 43:90

Santos L, Alves A, Alves R (2017) Evaluating multi-locus phylogenies for species boundaries determination in the genus Diaporthe. PeerJ 5:e3120

Smith H, Wingfield MJ, Coutinho TA, Crous PW (1996) Sphaeropsis sapinea and Botryosphaeria dothidea endophytic in Pinus spp. and Eucalyptus spp. in South Africa. S Afr J Bot 62:86-88

Sung GH, Sung JM, Hywel-Jones NL, Spatafora JW (2007) A multigene phylogeny of Clavicipitaceae (Ascomycota, Fungi): Identification of localized incongruence using a combinational bootstrap approach. Mol Phylogenet Evol 44:1204-1223

Swofford DL, Sullivan J (2003) Phylogeny inference based on parsimony and other methods using PAUP*. The Phylogenetic Handbook: A Practical Approach to DNA and Protein Phylogeny 160

Thomidis T, Michailides TJ (2009) Studies on Diaporthe eres as a new pathogen of peach trees in Greece. Plant Dis 93:1293-1297

Verkley GJ, da Silva M, Wicklow DT, Crous PW (2004) Paraconiothyrium, a new genus to accommodate the mycoparasite Coniothyrium minitans, anamorphs of Paraphaeosphaeria, and four new species. Stud Mycol 50:323-335

Verkley GJM, Dukik K, Renfurm R, Göker M, Stielow JB (2014) Novel genera and species of coniothyrium-like fungi in Montagnulaceae (Ascomycota). Pers Mol Phylogeny Evol Fungi 32:25

White TJ, Bruns T, Lee SJWT, Taylor J (1990) Amplification and direct sequencing of fungal ribosomal RNA genes for phylogenetics. PCR Protocols: a Guide to Methods and Applications 18:315-322

Yang Q, Fan XL, Guarnaccia V, Tian CM (2018) High diversity of Diaporthe species associated with dieback diseases in China, with twelve new species described. MycoKeys 39:97

Yilmaz N, Sandoval-Denis M, Lombard L, Visagie CM, Wingfield BD, Crous PW (2020) Redefining species limits in the Fusarium fujikuroi species complex. Pers Mol Phylogeny Evol Fungi 46:129-162

Zhang X, Sandhu A, Edirisinghe I, Burton-Freeman B (2018) An exploratory study of red raspberry (Rubus idaeus L.) (poly) phenols/metabolites in human biological samples. Food Funct 9:806-818

Zhang Y, Schoch CL, Fournier J, Crous PW, De Gruyter J, Woudenberg JHC et al (2009) Multi-locus phylogeny of Pleosporales: a taxonomic, ecological and evolutionary re-evaluation. Stud Mycol 64:85-102

Publisher's note Springer Nature remains neutral with regard to jurisdictional claims in published maps and institutional affiliations. 